Research Journal of Animal Sciences 4 (1): 10-15, 2010

ISSN: $1993-5269$

(C) Medwell Journals, 2010

\title{
Effects of Forage Level in Diet on Bacterial Protein Recycling in Goat Rumen
}

\author{
M.Z. Wang, L.H. Yu, H.R. Wang and X. Liu \\ College of Animal Science and Technology, Yangzhou University, \\ Yangzhou, 225009, P.R. China
}

\begin{abstract}
The objective of this study was to determine the effects of forage level on bacterial protein recycling in the rumen by Fluorescence-Labeled Bacteria technique (FLB). Four Xuhuai goats with permanent cannulas were used in a $4 \times 4$ Latin squares and diets were divided into A (86.96), B (67.63), C (48.31) and D (28.99\%) on the basis of forage level in diet. The results showed that rumen protozoal and bacterial populations were shifted heavily by diets $(\mathrm{p}<0.01)$ and $\mathrm{C}$ recorded the highest protozoal density while A demonstrated the lowest densities of protozoa and bacteria. Significant differences were detected in protozoa engulfing rates between groups $(\mathrm{p}<0.01)$ with the lowest value dropping in $\mathrm{B}$. It was also observed that $\mathrm{C}$ had the highest bacterial turnover rate and the shortest recycling time. Further estimation of bacterial protein recycling quantity per day per goat resulting from protozoa predation showed that $\mathrm{C}$ interpreted the highest bacterial protein recycling quantity while $\mathrm{B}$ had a lower bacterial protein recycling quantity, accounted for just $68.2 \%$ of that of group C. Results obtained here indicated that diets containing $67.63 \%$ forage could curb the bacterial protein recycling in some degree by regulating protozoal biomass and their ingestion action.
\end{abstract}

Key words: Forage level, rumen, protozoa, bacteria, engulfing rate, protein recycling, China

\section{INTRODUCTION}

Rumen microbes can degrade roughage or fibrous material to provide energy to the host animal. Also, rumen Microbial Protein (MCP) is good source of feed protein for ruminant. Studies show that the rumen MCP micro-recycling (ciliate protozoa ingestion on bacteria in rumen) will affect MCP yield with a bacterial protein recycling and lead to a low utilization efficiency of nitrogen (Wallace and McPherson, 1987). Dietary structure affects rumen fermentation and then alters the population and composition of rumen protozoa (Brown et al., 2006). On one hand, these changes of protozoa will directly affect MCP yield and on the other hand will affect MCP yield and N utilization efficiency indirectly, through altering the microbial recycling in rumen. This is also the reason why it is feasible to regulate nitrogen nutrition by regulating feeding behavior based on the digestive and absorptive characteristic of ruminant. Recently, some researches about MCP recycling have been done but most of these studies focus on the quantity of $\mathrm{MCP}$ flowing to duodenum and animal productivity under the conditions of faunation or defaunation (Hristov et al., 2004). However, researches on rumen micro-recycling are seldom seen and so the recycling rule of ruminal microbial is not clear at all even till now. It is however that the recycling rule is one of the essential points in the quantity prediction and regulation of MCP and meanwhile could offer references for protein nutrition control of ruminant. So, in this research, the Fluorescence Labeled Bacteria technique (FLB) was introduced to investigate engulfing rate of protozoa on bacteria in the rumen, the purpose was to study the effects of forage level on ruminal MCP recycling and also to offer some references for researches on the technique of $\mathrm{N}$ nutrition regulation in ruminant and the way for saving protein feedstuffs.

\section{MATERIALS AND METHODS}

Animals and diets: This experiment was conducted at the Experimental farm of Yangzhou University, Yangzhou, China and was approved by the Yangzhou University Animal Care Committee. Four Xuhuai goat wethers, 1 year old and weighing $27.8 \pm 2.5 \mathrm{~kg}$ BW, fitted with rumen cannulas were used in this experiment. The diet formulas used were showed in Table 1 and divided into A (86.96), B (67.63), C (48.31) and D (28.99\%) according to the forage ratio in diet. The goats were fed experimental diets to provide 1.3 times their maintenance metabolizable energy requirements (NRC, 1981) and the feeds were offered in two equal meals per day at 08:00 and 20:00. They also had free access to clean drinking water.

Corresponding Author: Mengzhi Wang, College of Animal Science and Technology, Yangzhou University, Yangzhou, 225009, P.R. China 
Res. J. Anim. Sci., 4 (1): 10-15, 2010

Table 1: Composition and nutrient levels of the experimental diets

\begin{tabular}{|c|c|c|c|c|}
\hline Ingredients & A & $\mathrm{B}$ & $\mathrm{C}$ & $\mathrm{D}$ \\
\hline Straw (\%) & 86.96 & 67.63 & 48.31 & 28.99 \\
\hline Com $(\%)$ & 0.97 & 17.39 & 38.65 & 60.87 \\
\hline Soybean meal (\%) & 8.70 & 11.59 & 9.66 & 6.76 \\
\hline Urea (\%) & 0.97 & 0.97 & 0.97 & 0.97 \\
\hline Dicalcium phosphate (\%) & 1.06 & 1.06 & 1.06 & 1.06 \\
\hline Salt (\%) & 0.77 & 0.77 & 0.77 & 0.77 \\
\hline $\operatorname{Premix}^{1}(\%)$ & 0.58 & 0.58 & 0.58 & 0.58 \\
\hline Total $(\%)$ & 100.00 & 100.00 & 100.00 & 100.00 \\
\hline \multicolumn{5}{|l|}{ Nutrient level $^{2}$} \\
\hline Metabolisim Energy (ME, $\mathrm{MJ} \mathrm{kg}^{-1}$ ) & 5.78 & 7.17 & 8.62 & 10.14 \\
\hline Dry Matter (DM, \%) & 91.84 & 91.26 & 90.63 & 89.99 \\
\hline Crude Protein (DM basis) (CP, \%) & 10.02 & 10.91 & 11.05 & 10.82 \\
\hline Non-Structure Carbohydrate (NSC, \%) & 23.71 & 33.64 & 45.89 & 58.56 \\
\hline Structure Carbohydrate $(\mathrm{SC}, \%)^{3}$ & 54.87 & 44.23 & 33.72 & 23.23 \\
\hline $\mathrm{NSC} / \mathrm{SC}$ & 0.43 & 0.76 & 1.36 & 2.52 \\
\hline
\end{tabular}

${ }^{1}$ The composition of premix: $\mathrm{FeSO}_{4} \cdot 7 \mathrm{H}_{2} \mathrm{O} 170 \mathrm{~g} \mathrm{~kg}^{-1} ; \mathrm{CuSO}_{4} \cdot 5 \mathrm{H}_{2} \mathrm{O} 70 \mathrm{~g} \mathrm{~kg}^{-1} ; \mathrm{MnSO}_{4} \cdot 5 \mathrm{H}_{2} \mathrm{O} 290 \mathrm{~g} \mathrm{~kg}^{-1} ; \mathrm{ZnSO}_{4} \cdot 7 \mathrm{H}_{2} \mathrm{O} 240 \mathrm{~g} \mathrm{~kg}^{-1} ; \mathrm{CoCl}_{2} \cdot 6 \mathrm{H}_{2} \mathrm{O} 510 \mathrm{mg}$ $\mathrm{kg}^{-1}$; KI $220 \mathrm{mg} \mathrm{kg}^{-1} ; \mathrm{Na}_{2} \mathrm{SeO}_{3} 130 \mathrm{mg} \mathrm{kg}^{-1}$; VA1, 620, $000 \mathrm{IU} \mathrm{kg}^{-1}$; VD3 324, $000 \mathrm{IU} \mathrm{kg}{ }^{-1}$; VE $540 \mathrm{IU} \mathrm{kg}^{-1}$; VK3 $150 \mathrm{mg} \mathrm{kg}^{-1}$; VB1 $60 \mathrm{mg} \mathrm{kg}{ }^{-1}$; VB2 $450 \mathrm{mg} \mathrm{kg}^{-1}$; VB12 $0.9 \mathrm{mg} \mathrm{kg}^{-1}$; VB5 1, $050 \mathrm{mg} \mathrm{kg}^{-1}$; Pantothenic acid calcium: $750 \mathrm{mg} \mathrm{kg}^{-1}$; Folacin $15 \mathrm{mg} \mathrm{kg}^{-1} ;{ }^{2} \mathrm{Analyzed} \mathrm{value;}^{3} \mathrm{SC}=\mathrm{NDF}-\mathrm{NDFN}$; $\mathrm{NSC}=100-((\mathrm{NDF}-\mathrm{NDFN})+\mathrm{CP}+\mathrm{EE}+\mathrm{ASH})$

Experimental design and sample manipulating: The animals were randomly assigned to four dietary treatments in a $4 \times 4$ Latin square design. Each experimental period consisted of a 14 days preliminary period and then followed by 6 days for rumen fluid sampling. Approximately, $100 \mathrm{~mL}$ digesta mixture was taken from rumen by using stomach tube on the first sampling day and immediately after collection, the ruminal microbial cell densities were examined. Mixture obtained from rumen on the 2 nd day and the $3 \mathrm{rd}$ day was used for making the bacteria-free rumen fluid and the Fluorescence-Labeled Bacteria (FLB), respectively. Rumen fluid obtained on the following sampling days was for engulfing rate testing. The sampling time of the consecutive 6 days ( 1 st- 6 th) was all set for 11:00 am.

Enumeration of bacteria and protozoa: For protozoa, rumen liquor was squeezed through two layer of gauze and then stained with an equal volume of MFS solution (containing $8 \mathrm{~g} \mathrm{~L}^{-1} \mathrm{NaCl}, 0.6 \mathrm{~g} \mathrm{~L}^{-1}$ methylgreen and $100 \mathrm{~mL} \mathrm{~L}^{-1}$ formaldehyde) at room temperature for $30 \mathrm{~min}$ and then the samples were observed by using microscope under the 40 objective. The eqution to calculate protozoa cells was presented here. Protozoa number $\mathrm{mL}^{-1}=$ $\mathrm{N} \times \mathrm{D} \times 4 \times 10^{4}$. Where, $\mathrm{N}$ is total number of protozoa in 4 middle panes and $\mathrm{D}$ is dilution times.

For bacteria, rumen liquor collection went through cellulose filter (pore size, $40 \mu \mathrm{m}$ ) and then diluted 10 , $100,1000,10000$ times with a crystal violet solution; subsequently, counted the bacteria using microscopy under a $100 \times$ oil-immersion objective. The equation to calculate bacterial number was: Bacteria number $\mathrm{mL}^{-1}=$ $\mathrm{N} / \mathrm{S} \times \mathrm{D} \times 16 \times 10^{4}$. Where, $\mathrm{N}$ is the sum of the pane-count; $\mathrm{S}$ is Number of panes counted and D is Dilution times.

Predation experiment: Engulfing experiment was carried out following Wang et al. (2008) and the method was described in detail. Bacteria free rumen fluid, rumen liquor were collected from each goat during each experimental period and centrifuged at $29000 \times \mathrm{g}$ for $20 \mathrm{~min}$ then the bacteria-free rumen fluid was numbered in series and stored at $4^{\circ} \mathrm{C}$ for 1 week before use.

Fluorescence Labeled Bacteria (FLB), Rumen fluid were collected from each goat during each experimental period and went through cellulose filter (pore size, $2 \mu \mathrm{m}$ ), then centrifuged at $22000 \times \mathrm{g}$ for $15 \mathrm{~min}$. Sediment was collected and washed 2 times using saline solution. After adding $2 \mathrm{~mL}$ DTAF (5-[4,6-dichlorotriazin -2-yl]amino fluorescein hydrochloride, Sigma) dyeing solution, the sample was incubated in a water bath kept at 60 for $2 \mathrm{~h}$ followed by centrifugation to throw away the DTAF dyeing solution, the sediment was washed 2 times and re-suspended in half volume of respective bacteria-free rumen fluid with the same number. And the FLB solution was stored at-20 for $<1$ week before use. Ingestion experiment. Rumen fluid were collected from each goat during each experimental period and went through cellulose filter (pore size, $80 \mu \mathrm{m}$ ), then centrifuged at $150 \times \mathrm{g}$ for $15 \mathrm{~min}$. Sediment was washed 2 times and re-suspended in half volume of respective bacteria-free rumen fluid with the same number.

Subsequently, the samples were incubated under similar condition as rumen inner environment $\left(\mathrm{O}_{2}\right.$-free, shaking and $39 /$ water bath) for $30 \mathrm{~min}$ to reactivate protozoa and then added equal volume of respective FLB solution with the same number to begin the ingestion experiment. Approximately, $1 \mathrm{~mL}$ subsamples were taken from medium at $5 \mathrm{~min}$ intervals for $40 \mathrm{~min}$ after ingestion experiment, the time series samples were inspected by epifluorescence microscopy, 3 repeats were set for each sampling-time point.

Covert coefficient and data statistics: Number of FLB were converted to biomass $\mathrm{N}$ using an average bacterial 
biovolume of $0.1 \mu \mathrm{m}^{3}$ and a nitrogen conversion factor of $0.054 \mathrm{pg} \mathrm{N}$ of $\mu \mathrm{m}^{3}$ (Wang et al., 2008). The data of the experiment was subjected to ANOVA (Analysis of Variance) (SPSS, ver.11.5) and the means were compared for significance by LSD (least significant difference test) at the $\mathrm{p}<0.05$ and regression analysis was subjected to the curve estimation procedure.

\section{RESULTS AND DISCUSSION}

Regression analysis: As time went on food was depositing and digesting in protozoal body and this then would reduce the ingestion velocity, consequently destroy the linear relationship between FLB number and time which affecting the reliability of calculation results.

Thus in order to ensure the validity of results, it was very important to determine the time of ingestion experiment. Referring to the previous studies of the lab, the regression analysis time was set to $25 \mathrm{~min}$. The results of the 1st experimental period were shown in Table 2 and it was clearly that the FLB cell numbers engulfed by protozoa increased with incubation time up to $25 \mathrm{~min}$. Furthermore, the $\mathrm{r}$ values of the linear equations were all higher than 0.956 indicating a good linear relationship between FLB cell numbers and time within $25 \mathrm{~min}$. Additionally, the fluorescence photography showed that the 25-min photo (Fig. 1) was clear enough to count the FLB cells ingested by protozoa, however, the longer the experimental time was, the blurrier the FLB cells in protozoal body was, the $40 \mathrm{~min}$ photo (Fig. 2) was difficult to identify and count FLB cells inside the protozoa body. Therefore, $25 \mathrm{~min}$ was reasonable based on the experimental condition of this research. The linear regression analysis between the FLB cell numbers and time within $25 \mathrm{~min}$ were done and the equ of the first experimental period were list as follows:

$$
\begin{aligned}
& A 1: Y=12.9577+7.1818 X(r=0.975, t=9.155, p=0.000) \\
& B 1: Y=12.6594+6.0985 X(r=0.961, t=7.811, p=0.001) \\
& C 1: Y=14.1023+6.3985 X(r=0.956, t=7.266, p=0.001)
\end{aligned}
$$

D1: $\mathrm{Y}=12.4545+6.7041 \mathrm{X}(\mathrm{r}=0.967, \mathrm{t}=8.439, \mathrm{p}=0.000)$

Where, Y-FLB cell numbers engulfed by protozoa (cells/cell), X-time (min). According to regression equations, the predation rate were $430.92 \mathrm{cells} /(\mathrm{cell} \mathrm{h}$ ), $365.88 \mathrm{cells} /($ cell h), $383.88 \mathrm{cells} /($ cell h) and 402.24 cells/(cell h) for A1, B1, C1 and D1, respectively and then obtained the engulfing rates of the other 3 experimental periods in the same way.

Microbial ecosystem: The results (Table 3 ) showed that the protozoal highest density was observed in $\mathrm{C}$ while the opposite was found in A. Bacterial density was highest in $\mathrm{B}$ and the reverse was true for $\mathrm{A}$, recording the lowest density. The differences were all significant. From Table 3 , it was also clearly that, engulfing rates were varied with diets $(p<0.01)$. Except A, engulfing rates had a tendency of increase with the decrease of straw level in diet, with $B$ recording the lowest value ( 366.74 cells $/$ cell h). Additionally, the results (Table 3) demonstrated that $\mathrm{C}$ recorded the highest bacterial turnover rate $(3.07 \%)$ and the shortest recycling time $(32.6 \mathrm{~h})$; the other way round, $\mathrm{B}$ interpreted the lowest turnover rate $(2.02 \%)$ and the longest recycling time $(49.4 \mathrm{~h})$ and $\mathrm{A}$ had a similar bacterial recycling rate $(2.95 \%)$ and recycling time $(33.9 \mathrm{~h})$ as $\mathrm{C}$.

MCP recycling: When the corresponding values of engulfing rates expressed as bacteria- $\mathrm{N}$ (Table 3) the recycling rates of $\mathrm{N}$ were: $2.319 \mathrm{pg} \mathrm{N} /($ cell h) $1.980 \mathrm{pg}$ $\mathrm{N} /$ (cell h), $2.103 \mathrm{pg} \mathrm{N} /$ (cell h) and $2.172 \mathrm{pg} \mathrm{N} /$ (cell h) for A, $\mathrm{B}, \mathrm{C}$ and $\mathrm{D}$, respectively. Further extrapolating the assimilation quantity of bacterial nitrogen by protozoa per goat per day on the basis of an estimation of $4 \mathrm{~L}$ of goat's rumen content (Zhao, 2004) was also shown in Table 3. It was estimated that bacterial protein recycling quantity using a conversion factor of $6.25 \mathrm{Pr} / \mathrm{N}$, respectively, were, $0.853 \mathrm{~g} \mathrm{Pr} /(\mathrm{d}$ capita), $2.306 \mathrm{~g} \mathrm{Pr} /(\mathrm{d}$ capita), $3.370 \mathrm{~g} \mathrm{Pr} /(\mathrm{d}$ capita) and $2.754 \mathrm{~g} \operatorname{Pr} /(\mathrm{d}$ capita), with $\mathrm{C}$ interpreting the

\begin{tabular}{|c|c|c|c|c|c|c|c|c|}
\hline \multirow[b]{2}{*}{$\begin{array}{l}\text { Time } \\
\text { points } \\
\text { (min) }\end{array}$} & \multicolumn{2}{|l|}{$\mathrm{A} 1$} & \multicolumn{2}{|l|}{ B1 } & \multicolumn{2}{|l|}{$\mathrm{C} 1$} & \multicolumn{2}{|l|}{ D1 } \\
\hline & $\begin{array}{l}\text { Engulfing } \\
\text { number } \\
\text { (cells/cell) }\end{array}$ & $\begin{array}{l}\text { Engulfing } \\
\text { rate } \\
\text { (cells/cell h) }\end{array}$ & $\begin{array}{c}\text { Engulfing } \\
\text { number } \\
\text { (cells/cell) }\end{array}$ & $\begin{array}{l}\text { Engulfing } \\
\text { rate } \\
\text { (cells/cell h) }\end{array}$ & $\begin{array}{c}\text { Engulfing } \\
\text { number } \\
\text { (cells/cell) }\end{array}$ & $\begin{array}{l}\text { Engulfing } \\
\text { rate (cells } \\
\text { /cell h) }\end{array}$ & $\begin{array}{c}\text { Engulfing } \\
\text { number } \\
\text { (cells/cell) }\end{array}$ & $\begin{array}{l}\text { Grazing } \\
\text { rate } \\
\text { (cells/cell) }\end{array}$ \\
\hline 2 & 15.70 & 471.0 & 14.3 & 429.00 & 14.7 & 441.00 & 14.0 & 420.0 \\
\hline 5 & 55.00 & 660.0 & 43.0 & 516.00 & 46.0 & 552.00 & 47.0 & 564.0 \\
\hline 10 & 107.7 & 646.2 & 102.7 & 616.20 & 111.7 & 670.20 & 108.7 & 652.2 \\
\hline 15 & 138.3 & 553.2 & 119.3 & 477.20 & 125.7 & 502.80 & 129.0 & 516.0 \\
\hline 20 & 146.3 & 438.9 & 129.6 & 388.80 & 137.0 & 411.00 & 139.7 & 419.1 \\
\hline 25 & 180.7 & 426.5 & 149.3 & 358.32 & 156.3 & 375.12 & 165.0 & 396.0 \\
\hline
\end{tabular}
highest bacterial protein recycling quantity.

Table 2: The number and rate of protozoa engulfing on FLB of the first experimental period in $4 \times 4$ Latin square

$\mathrm{A} 1, \mathrm{~B} 1, \mathrm{C} 1$ and $\mathrm{D} 1$ were diets containing $86.96,67.63,48.31$ and $28.99 \%$ for age, respectively of the first experimental period in $4 \times 4$ Latin square 
Population of rumen microbes: Researches showed that the favorite substrates of protozoa are starch and soluble polysaccharides and the largest size of protozoa population will be observed in rumen when the forage ratio in diet ranged from $40-50 \%$ while high-concentrate diet will reduce rumen $\mathrm{pH}$ and protozoa population might shrink or disappearance resultantly (Zhu, 2004). In this study, the peak value of protozoal density occurred in group C (48.31\%) and protozoal density had a tendency towards increase with the increase of concentrate but there was a decline in group D $(28.99 \%)$, agreed with the previous works described above. Unreasonable dietary structure would affect the synthetic efficiency of MCP and ruminant productivity. Firkins (1996) suggested that in order to obtain the highest synthetic efficiency of MCP, ruminant diet should have a reasonable ratio of grain and fat. A similar report by Yang and Feng (2003) showed that the MCP yield in RSI was lowest in the substrate with the highest level of cellulose inclusion and the synthetic efficiency of MCP was shifted by cellulose ratio.

In current research, the microbial populations were modified by diets and conformed to the above previous reports in some degree. It was also proved that high-forage diet was usually unfavorable for microbial growth. In a certain micro ecosystem, protozoa and

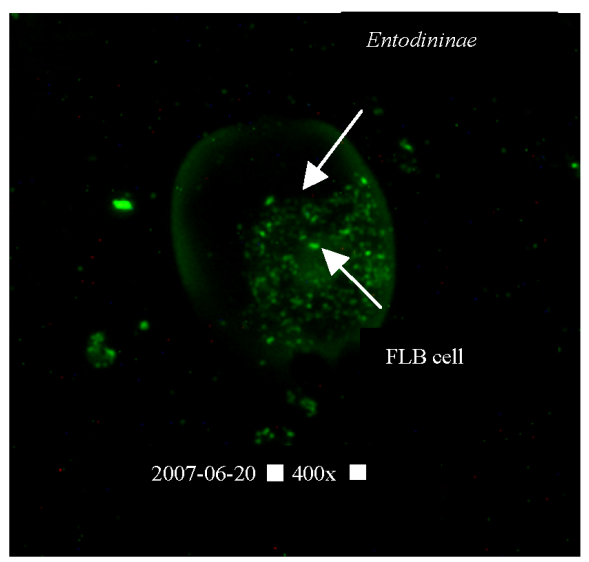

Fig. 1: The 25 min fluorescent photo of protozoa with FLB cell bacteria would impact each other, bacterial populations are constrained by the action of protozoa predation while the size and structure of bacteria populations would in turn affect the action of protozoa predation on it. Some kinds of bacteria could even defend against protozoa predation (Lebaron et al., 2001; Zhang et al., 2001; $\mathrm{Xu}$ et al., 2004a). Nhan et al. (2007) reported that bacterial density decreased with the increase of protozoa density in cattle rumen and suggested that ruminal bacteria and protozoa always interacted with each other.

Currently, the bacterial density of group C decreased by $13.08 \%$ compared to group B. The most probable reason was that the protozoal predation pressure of group $\mathrm{C}$ increased, due to the protozoal density increased by $22.01 \%$ from group B to group C and agreed with the results described in the previous report (Xu et al., 2004a).

Engulfing rate: In this study, the engulfing rates of all groups falling within the range of $10^{2}-10^{4}$ cells/(cell h) was generally recognized as the range of engulfing rates of rumen protozoa. The extrapolation of protein recycling also concurred with previous report by Coleman (1979),

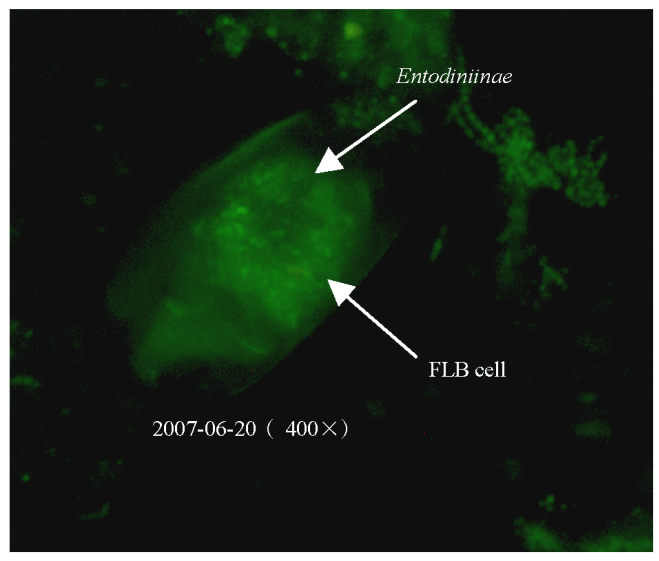

Fig. 2: The $40 \mathrm{~min}$ fluorescent photo of protozoa with FLB cell, FLB was rumen bacteria stained with DTAF (5-([4,6-dichlorotriazin-2-yl]amino) fluorescein hydrochl- orid time $(33.9 \mathrm{~h})$ as $\mathrm{C}$

Table 3: Effects of dietary forage level on rumen microbial densities and bacteria recycling

\begin{tabular}{|c|c|c|c|c|c|c|}
\hline Items & A & $\mathrm{B}$ & $\mathrm{C}$ & $\mathrm{D}$ & SEM & $\overline{p \text {-value }}$ \\
\hline Protozoa density $\left(\times 10^{5}\right.$ cells $\left.\mathrm{mL}^{-1}\right)$ & $6.130^{\mathrm{a}}$ & $19.410^{\mathrm{b}}$ & $24.070^{c}$ & $21.130^{\mathrm{bc}}$ & 1.69625 & 0.000 \\
\hline Bacteria density $\left(\times 10^{9}\right.$ cells $\left.\mathrm{mL} \mathrm{L}^{-1}\right)$ & $8.920^{\mathrm{a}}$ & $35.180^{\mathrm{b}}$ & $30.580^{\mathrm{c}}$ & $31.270^{\mathrm{bc}}$ & 2.06950 & 0.000 \\
\hline Engulfing rates (cells/cell h) & $429.500^{\mathrm{d}}$ & $366.740^{\mathrm{a}}$ & $389.480^{\mathrm{b}}$ & $402.200^{c}$ & 2.73453 & 0.000 \\
\hline Engulfing quantity $\left(\times 10^{5}\right.$ cells $\left.\mathrm{mL}^{-1} \mathrm{~h}\right)$ & 2632.840 & 7118.420 & 9374.780 & 8498.490 & - & - \\
\hline Bacteria recycling rates $(\%)$ & 2.950 & 2.020 & 3.070 & 2.720 & - & - \\
\hline Bacteria recycling time $(\mathrm{h})$ & 33.900 & 49.400 & 32.600 & 36.800 & - & - \\
\hline $\mathrm{N}$ recycling rates ( $\mathrm{pg} / \mathrm{cell} \mathrm{h}$ ) & 2.319 & 1.980 & 2.103 & 2.172 & - & - \\
\hline $\mathrm{N}$ recycling quantity ( $\mathrm{mg} \mathrm{d}^{-1}$ capita) & 136.490 & 369.020 & 485.990 & 440.560 & - & - \\
\hline Pr recycling quantity ( $\mathrm{g} \mathrm{d}^{-1}$ capita) & 0.853 & 2.306 & 3.370 & 2.754 & - & - \\
\hline
\end{tabular}

${ }^{1} \mathrm{~A}, \mathrm{~B}, \mathrm{C}$ and D were diets containing $86.96,67.63,48.31$ and $28.99 \%$ forage, respectively. ${ }^{2}$ The same superscript letters within the same row indicated that the means were not significantly different $(p>0.05)$; neighbor letters were significantly different $(p<0.05)$; parted letters were extremely different $(p<0.01)$ 
with the quantitative estimation of bacteria protein recycling of $2.5-4.5 \mathrm{~g} /(\mathrm{d}$ capita) in rumen. Many factors will disturb the protozoa engulfing rate including the physical-chemical properties of growth environments $(\mathrm{pH}$, Eh and $\mathrm{NH}_{3}$, etc.), protozoa itself (genus, growth period, cell density, etc.), food density and so on (Hong et al., 2001; Xu et al., 2004b). As far as food density is concerned, when the food density is low, engulfing rate has direct relationship with food density but when the food density is up to a certain level, even though food density increases, engulfing rate won't increase with it any more, quite the reverse, predation rate and propagation rate (Lang et al., 2003) might decrease due to the further increase of food density. In current study, grazing rate of group A was highest while group B was lowest. The one reason maybe that group $B$ had a higher bacteria density than group $\mathrm{A}$. Another possible reason was that different protozoa genus would be selected by different diets and meanwhile different protozoa genus had different engulfing rate (Hong et al., 2001; Simek et al., 1995). This then led to various engulfing rates according to diets resultantly. Anyway, the rumen micro ecosystem is complex and the factors affecting the protozoa engulfing rate are not very clear thus these results or estimations should be verified by further experiments.

Recycling rate and recycling quantity: Previous researches showed that bacteria recycling rates ranged from $0.3-2.7 \%$ without protozoa while ranged between 2.4-3.7\% with protozoa ( $\mathrm{Zhu}, 2004$ ). Therefore, the existence of protozoa could cause the insignificant MCP recycling in the rumen and leading to a low efficiency of $\mathrm{N}$ utilization in ruminant (Leng, 1982; Jounay, 1996; Koenig et al., 2000; Ivan et al., 2000). And it is a main channel for $\mathrm{N}$ nutrition control in ruminant, to regulate MCP yield through regulating protozoa population (Santra and Pathak, 2001) and for N nutrition control, it is necessary and important to clarify the recycling rule behind the variations of microbial community. In this research, the highest recycling rate $(3.07 \%)$ and the shortest recycling time $(32.6 \mathrm{~h})$ were recorded by group $\mathrm{C}$ (48.31\%) and that was to say, bacteria would be circulated one time per $32.6 \mathrm{~h}^{-1}$. In contrast, group B $(67.63 \%)$ interpreted the lowest recycling rate $(2.02 \%)$ and the longest recycling time $(49.4 \mathrm{~h})$ and revealed that, this group took a long time for protozoa to renew bacteria. Further extrapolation of the MCP recycling quantity, showed that group $\mathrm{B}$ had a lower recycling quantity of $2.306 \mathrm{~g} /(\mathrm{d}$ capita $)$ accounted for just $68.2 \%$ of that of group $\mathrm{C}(3.370 \mathrm{~g} /(\mathrm{d}$ capita $))$ and revealed that diets containing $67.63 \%$ forage could curb the MCP recycling in some degree by regulating protozoa biomass and their ingestion action. It was surprise that group A $(86.96 \%)$ which the microbial population densities were lowest but had a higher MCP recycling rate $(2.95 \%)$ and shorter recycling time $(33.9 \mathrm{~h})$ being similar to the group $\mathrm{C}$ and revealed that the MCP synthesis would be modified easily by protozoa predation when a high-forage diet was provided.

\section{CONCLUSION}

In conclusion, microbial populations, protozoal engulfing rates and the bacterial protein recycling in rumen were all manipulated by dietary forage levels. Group C (48.31\%) interpreted the highest quantity of bacterial protein recycling $(3.370 \mathrm{~g} \mathrm{Pr} /(\mathrm{d}$ capita $)$ ) while $\mathrm{B}$ $(67.63 \%)$ had a lower recycling quantity $(2.306 \mathrm{~g} /(\mathrm{d}$ capita)) accounted for just $68.2 \%$ of that of group $\mathrm{C}$ and indicated that the diets containing $67.63 \%$ forage could curb the MCP recycling in some degree by regulating protozoal biomass and their ingestion.

\section{ACKNOWLEDGEMENT}

This study was a part of project (No. 30771567) which supported by the National Natural Science Foundation of China (NSFC).

\section{REFERENCES}

Brown, M.S., C.H. Ponce and R. Pulikanti, 2006. Adaptation of beef cattle to high-concentrate diets: Performance and ruminal metabolism. J. Anim. Sci., 84: 25-33.

Coleman, G.S., 1979. The role of rumen protozoa in the metabolism of ruminants given tropical feeds. Trop. Anim. Prod., 4: 199-213.

Firkins, J.L., 1996. Maximizing microbial protein synthesis in the rumen. J. Nutr., 126: 1347S-1354S.

Hong, H.S., L. Ke, B.Q. Huang and X.J. Lin, 2001. The grazing rate of strombidium sucaltum, using a modified fluorescence-labeled technique. Oceanol. Limnol. Sinica, 32: 260-266.

Hristov, A.N., K.L. Grandeen, J.K. Ropp and M.A. McGuire, 2004. Effect of sodium laurate on ruminal fermentation and utilization of ruminal ammonia nitrogen for milk protein synthesis in dairy cows. J. Dairy Sci., 87: 1820-1831.

Ivan, M., L. Neill, R. Forster, R. Alimon, L.M. Rode and T. Entz, 2000. Effects of isotricha, dasytricha, entodinium and total fauna on ruminal fermentation and duodenal flow in wethers fed different diets. J. Dairy Sci., 83: 776-787. 
Jounay, J.P., 1996. Effect of rumen protozoa on nitrogen utilization by ruminants. J. Nutr., 126: 1335-1336.

Koenig, K.M., C.J. Newbold, F.M. McIntosh and L.M. Rode, 2000. Effects of protozoa on bacterial nitrogen recycling in the rumen. J. Anim. Sci., 78: 2431-2445.

Lang, P., X. Huang, Y. Qian and G.J. Ding, 2003. Progression on technique of reducing sludge production. Chinese J. Environ. Sci., 4: 44-52.

Lebaron, P., P. Servais, M. Troussellier, C. Courties and G. Muyzer et al., 2001. Microbial community dynamics in Mediterranean nutrient-enriched seawater mesocosms: Changes in abundances, activity and composition. FEMS Microbiol. Ecol., 34: 255-266.

Leng, R.A., 1982. Dynamics of protozoa in the rumen of sheep. Br. J. Nutr., 48: 399-415.

NRC, 1981. National Research Council, Nutritional Energetics of Domestic Animals and Glossary of Energy Terms. National Academy Press, Washington, DC.

Nhan, N.T.H., N.T. Ngu, N. Thiet, T.R. Preston and R.A. Leng, 2007. Determination of the optimum level of a soybean oil drench with respect to the rumen ecosystem, feed intake and digestibility in cattle. Livest. Res. Rural Dev., 19: 117-118.

Santra, A. and N.N. Pathak, 2001. The effect of dietary concentrate level on rumen enzyme profile and ciliate protozoa population in cattle fed wheat straw diet. J. Anim. Feed Sci., 10: 589-604.

Simek, K., J. Bobkova, M. Macek and J. Nedoma, 1995. Ciliate grazing on picoplankton in a eutrophic reservoir during the summer phytoplankton maximum: A study at the species and community level. Limnol. Oceanogr., 40: 1077-1090.
Wallace, R.J. and C.A. McPherson, 1987. Factors affecting the rate of breakdown of bacterial protein in rumen fluid. Br. J. Nutr., 59: 313-323.

Wang, M.Z., H.R. Wang, G.X. Li, H.C. Cao and Z.J. Lu, 2008. The preliminary report on rumen protozoa grazing rate on bacteria with fluorescence-labeled technique. Sci. Agric. Sinica, 7: 101-105.

Xu, H.L., M. Wang, M.Z. Zhu and W.B. Song, 2004a. Experimental ecological study on marine ciliates: Grazing stress of marine ciliated protozoan on the growth of Vibrio sp. Popul. Chinese J. Applied Environ. Biol., 10: 75-78.

Xu, H.L., M. Wang, M.Z. Zhu and W.B. Song, 2004b. Effects of population growth of marine ciliates on the ammonia accumulation at different concentrations of glucose. Acta Zool. Sinica, 50: 551-558.

Yang, H.J. and Y.L. Feng, 2003. Effect of cellulose to starch ratio in substrate on in vitro microbial protein yield with equal nitrogen purified substrate. Chinese J. Anim. Sci., 39: 7-9.

Zhang, S.L., H.G. Ma, H.L. Xu and W.B. Song, 2001. On experimental ecology of the marine ciliate paranophrys magna IV: Effects of competition on population growth. Acta Ecologica Sinica, 21: 2039-2044.

Zhao, G.J., 2004. The Property of Rumen and Ruminal Content. In: Ruminant Nutrition, Feng, Y.L. (Ed.). Science Press, Beijing, pp: 131-135.

Zhu, W.Y., 2004. Rumen Microbiology. In: Ruminant Nutrition, Feng, Y.L. (Ed.). 1st Edn., Science Press, Beijing, pp: 66-69. 